\title{
Multidrug-resistant tuberculosis in Port-au-Prince, Haiti
}

\author{
Oksana Ocheretina, ${ }^{1}$ Willy Morose, ${ }^{2}$ Marie Gauthier, ${ }^{3}$ Patrice Joseph, ${ }^{2}$ \\ Richard D'Meza, ${ }^{4}$ Vincent E. Escuyer,${ }^{5}$ Nalin Rastogi, ${ }^{6}$ Guy Vernet, ${ }^{3}$ \\ Jean W. Pape, ${ }^{2}$ and Daniel W. Fitzgerald ${ }^{1}$
}

Suggested citation Ocheretina O, Morose W, Gauthier M, Joseph P, D'Meza R, Escuyer VE, et al. Multidrug-resistant tuberculosis in Port-au-Prince, Haiti. Rev Panam Salud Publica. 2012;31(3):221-4.

\begin{abstract}
Objective. To determine the prevalence of multidrug-resistant tuberculosis (MDR-TB) among patients with new smear-positive pulmonary TB in Port-au-Prince, Haiti.

Methods. Sputum samples were cultured from 1006 patients newly diagnosed with TB in 2008. The core region of the $\mathrm{rpoB}$ gene that is associated with resistance to rifampin was sequenced. All isolates with rpoB mutations were sent to the New York State reference laboratory for conventional drug susceptibility testing (DST). All isolates were also tested with the GenoType MTBDRplus line-probe assay.

Results. Mycobacterium tuberculosis was isolated from 906 patients. Twenty-six (2.9\%) of the isolates had missense mutations or deletions in $\mathrm{rpoB}$ and were resistant to rifampin by DST. All 26 were also resistant to isoniazid and classified as MDR-TB. Forty-six control isolates without $\mathrm{rpoB}$ mutations were found to be rifampin sensitive by DST. The GenoType MTBDRplus line-probe assay correctly identified 26 MDR-TB strains. It misclassified one pansusceptible isolate as rifampin resistant.

Conclusions. This study shows an MDR-TB prevalence of $2.9 \%$ in newly diagnosed $T B$ patients in Haiti and suggests that $\mathrm{rpoB}$ sequencing and hybridization assays are good screening tools for early detection of MDR-TB.
\end{abstract}

Key words Tuberculosis, multidrug resistant; cross-sectional studies; Haiti.

Haiti has the highest rate of tuberculosis (TB) in the Western Hemisphere,

\footnotetext{
Center for Global Health, Division of Infectious Diseases, Department of Medicine, Weill Cornell Medical College, New York, New York, United States of America. Send correspondence to: O. Ocheretina, oko2001@med.cornell.edu

2 Les Centres GHESKIO, Port-au-Prince, Haiti.

3 Fondation Mérieux, Lyon, France.

4 Programme Nationale de Lutte contre la Tuberculose, Ministère de la Santé Publique et de la Population, Port-au-Prince, Haiti.

5 Laboratory of Clinical Mycobacteriology, Wadsworth Center, New York State Department of Health, Albany, New York, United States of America.

6 World Health Organization Supranational Tuberculosis Reference Laboratory, Institut Pasteur de la Guadeloupe, Pointe-à-Pitre, Guadeloupe, France.
}

with an estimated prevalence of 331 per 100000 population (1). Because of longstanding poverty and political instability, a significant number of Haitians emigrate to countries around the world. In 2010, the World Bank reported that approximately 1 million Haitians, or nearly $10 \%$ of Haiti's resident population, were living abroad in countries that include the Dominican Republic, the Bahamas, the United States of America, Canada, France, and other parts of the francophone world (2). Haiti was the most frequent country of birth among foreign-born TB patients in Montreal, where Haitians account for $18.5 \%$ of all
TB cases, and the fifth most frequent in New York, with $5.0 \%$ of all TB cases $(3,4)$. Therefore, an understanding of Mycobacterium tuberculosis strains circulating in Haiti, especially drug-resistant strains, has both country-specific and global health significance $(5,6)$.

Findings from the three $M$. tuberculosis drug-resistance prevalence studies conducted over the past 20 years suggest that the rate of drug resistance may be increasing in Haiti. In a 1990 study, the rate of isoniazid resistance was $19 \%$ but multidrug-resistant tuberculosis (MDRTB), defined as resistance to both isoniazid and rifampin, was not found in any 
patient newly diagnosed with TB (7). In a 1991 study of recent migrants from Haiti to Cuba, monoresistance to isoniazid was found in $22 \%$ of TB patients but MDR-TB was not found (8). However, a study in 2002 of patients presenting to an HIV/AIDS center in Port-au-Prince, Haiti, with new onset tuberculosis found a rate of primary MDR-TB of $6 \%$ (9). The 2002 study was small and limited to a single HIV testing center but suggested an increase in MDR-TB.

In 2010, the World Health Organization (WHO) estimated that $3.4 \%$ of new TB cases globally and $2.1 \%$ of new cases in the Americas were MDR-TB (1). In the Caribbean, rates of MDR-TB range from $<1.0 \%$ of new cases in Cuba to $6.6 \%$ in the Dominican Republic $(10,11)$. Because of limited data on drug resistance, the WHO has not provided a definitive assessment of trends in MDR-TB over time globally or in the Americas. It is hoped that with recent advances in molecular techniques, more drugresistance data will be forthcoming and the WHO will be able to determine whether the prevalence of MDR-TB is increasing.

A survey of TB drug resistance at the five largest TB treatment centers in Portau-Prince was conducted to determine the prevalence rates of primary MDR-TB and to determine whether there has been an increase since 1990. A secondary objective of this study was to validate the use of molecular tests for the diagnosis of MDR-TB in Haiti before their clinical application.

\section{METHODS}

\section{Study design}

This was a cross-sectional prevalence study of $M$. tuberculosis drug resistance among patients presenting with new acid-fast bacillus smear-positive active pulmonary tuberculosis at the five largest TB treatment centers in the metropolitan Port-au-Prince area in 2008. Sputum samples were cultured from these five centers for $M$. tuberculosis. Isolates were then examined by sequence analysis of the $r p o B$ gene, which is known to be associated with $>95 \%$ of rifampin resistance (12). M. tuberculosis isolates resistant to rifampin by rроB DNA sequence analysis were sent to the Mycobacteriology Laboratory of the New York State Department of Health for drug susceptibility testing (DST). A subset of isolates negative for rifampin resistance by $r p o B$ gene analysis was also sent to the New York reference laboratory. The prevalence of MDR isolates is reported, defined as isolates that were resistant to rifampin by $r p o B$ gene analysis with confirmation of resistance to rifampin and isoniazid by DST at the New York reference laboratory.

\section{Study setting and population}

The five tuberculosis centers in Portau-Prince and its environs included Grace Children's Hospital, the Haitian State Sanatorium, GHESKIO Centers, Sigueneau Sanatorium, and the Mennonite Mission of Croix des Bouquets. These centers cover about $75 \%$ of all TB cases treated in the Port-au-Prince area. The patients were consecutively diagnosed with an acid-fast bacillus-positive smear in 2008. They did not report a prior diagnosis of TB.

A laboratory technician placed a 2- to 5 -mL aliquot of sputum from each patient into a 50-mL plastic tube. The tube was labeled with the patient's age, gender, and HIV status (positive, negative, unknown). The sample was refrigerated at $4^{\circ} \mathrm{C}$ and transported within 2 days to a central laboratory at the GHESKIO Centers.

\section{Laboratory studies}

Sputum samples were decontaminated with sodium lauryl sulfate and cultured on Lowenstein-Jensen slants (Becton Dickenson, Franklin Lakes, New Jersey, United States of America). For positive cultures, a loopful of mycobacteria was resuspended in $300 \mu \mathrm{L}$ of nuclease-free water, heat-killed by $20 \mathrm{~min}$ of incubation at $95^{\circ} \mathrm{C}$, and disrupted by three cycles of freezing at $-70^{\circ} \mathrm{C}$ and heating at $95^{\circ} \mathrm{C}$. DNA was separated from debris using Spin- $X$ centrifuge filter tubes, 0.22- $\mu \mathrm{m}$ pore size (COSTAR, Corning Inc., Lowell, Massachusetts, United States). The 329-bp rроB fragment was amplified in 35 cycles of polymerase chain reaction (PCR). PCR parameters were $30 \mathrm{~s}$ of denaturation at $95^{\circ} \mathrm{C}, 1 \mathrm{~min}$ of annealing at $55^{\circ} \mathrm{C}$, and 1 min of extension at $72^{\circ} \mathrm{C}$. Each $50-\mu \mathrm{L}$ reaction mixture consisted of $5 \mu \mathrm{L}$ of DNA extract, $0.2 \mu \mathrm{M}$ each primers $r p o B-F$ (5'-CCACCC-AGG-ACG-TGG-AGG-CGA-TCACAC-3') and rpoB-R (5'-CGT-TTC-GATGAA-CCC-GAA-CGG-GTT-GAC-3'),
$200 \mathrm{mM}$ dNTPs, and 1.25 units of HotStart Taq polymerase (QIAGEN, Hilden, Germany) in buffer provided with plymerase kit.

PCR fragments were purified with a QIAquick PCR purification kit (QIAGEN, Hilden, Germany), premixed with the primers used for PCR amplification, and sent for Sanger (3730XL) sequencing at Cornell University Bio Resource Center (Ithaca, New York, United States). The sequences obtained were compared with the wild-type $r p o B$ sequence of $\mathrm{H} 37 \mathrm{Rv}$ for $M$. tuberculosis complex identification and for detection of mutations. Isolates were provisionally classified as rifampin resistant if they had a polymorphism previously described as conferring resistance (12).

DNA extracts from all isolates were tested for mutations associated with resistance to isoniazid and rifampin by a commercially available line-probe assay according to the manufacturer's instructions (GenoType MTBDRplus, Hain Life Sciences, Nehren, Germany). The operator performing the test was blinded to the results of $r p o B$ sequence analysis.

All isolates with rpoB mutations, along with a subset of isolates without $r p o B$ mutations, were sent to the Laboratory of Clinical Mycobacteriology, Wadsworth Center, New York State Department of Health (Albany, New York, United States). All specimens were confirmed as $M$. tuberculosis complex by real-time PCR assay (13). In New York, drug sensitivity testing to first-line antituberculosis drugs was performed in Mycobacteria growth indicator tubes (BACTEC 960, Becton Dickenson, Franklin Lakes, New Jersey, United States) in accordance with the manufacturer's instructions. For isolates resistant to at least one first-line drug, DST to isoniazid, rifampin, ethambutol, streptomycin, capreomycin, cycloserine, ethionamide, kanamycin, $p$-aminosalicylc acid, amikacin, and ofloxacin was performed with the proportion method on 7H10 agar as recommended by the Clinical and Laboratory Standards Institute (14).

\section{Analysis}

The prevalence, with $95 \%$ confidence intervals, of MDR-TB at five major TB treatment centers around Port-au-Prince is reported. Proportions were compared using Fisher's exact test and medians with the Wilcoxon rank sum test. This 
study was approved by the Institutional Review Board at GHESKIO and Weill Cornell Medical College (New York).

\section{RESULTS}

\section{Study population}

The five sites sent sputum samples from 1006 patients to the central laboratory at GHESKIO for analysis. Of them, 909 grew Mycobacteria on LowensteinJensen media and yielded DNA extracts suitable for PCR sequencing. Of the 909 isolates, 906 belonged to the $M$. tuberculosis complex. The characteristics of the 906 patients from whom M. tuberculosis was isolated are presented in Table 1. The median age was 30 years, $49.1 \%$ were female, and $77.9 \%$ of patients were HIV-1 seronegative. Each site contributed approximately the same number of samples.

\section{Prevalence of MDR-TB}

The 81-bp core region of the $r p o B$ gene was sequenced for all isolates. Of the 906 M. tuberculosis isolates, 27 (2.9\%) contained missense mutations or deletions in the $r p o B$ gene that are known to be associated with rifampin resistance. One additional isolate had a silent mutation or synonymous single nucleotide polymorphism in $r p o B$ codon T508 (ACC $\rightarrow$ ACT).

The $27 \mathrm{M}$. tuberculosis isolates with missense mutations or deletions in $r p o B$ were sent to the New York State TB

TABLE 1. Characteristics of 906 patients with a diagnosis of new onset sputum smearpositive tuberculosis, Port-au-Prince, Haiti, 2008

\begin{tabular}{lcc}
\hline \multicolumn{1}{c}{ Characteristic } & No. & $\%^{\mathrm{a}}$ \\
\hline Age, years & 30 & NA \\
$\quad$ Median & & \\
$\quad$ Interquartile range & $20-41$ & NA \\
Female & 445 & 49.1 \\
HIV status & & \\
$\quad$ Positive & 115 & 12.7 \\
$\quad$ Negative & 706 & 77.9 \\
$\quad$ Unknown & 85 & 9.4 \\
Site & & \\
$\quad$ Grace Children's Hospital & 226 & 24.9 \\
State Tuberculosis & & \\
$\quad$ Sanatorium & 190 & 21.0 \\
$\quad$ GHESKIO Centers & 182 & 20.1 \\
$\quad$ Sigueneau Sanatorium & 120 & 13.2 \\
$\quad$ Mennonite Mission of & & \\
$\quad$ Croix des Bouquets & 188 & 20.7 \\
\hline
\end{tabular}

Note: NA: not applicable.

a May not sum to 100 due to rounding.
Laboratory. Twenty-six isolates grew in New York, and one isolate was nonviable upon subculture. All 26 isolates that grew in New York were confirmed as M. tuberculosis. All 26 isolates tested resistant to rifampin by conventional culture DST on solid and liquid media. All 26 were also resistant to isoniazid and hence were classified as MDR-TB. The complete drug sensitivity profile of the 26 MDR isolates is shown in Table 2.

In total, 26 of 906 (2.9\%) M. tuberculosis isolates were confirmed to be MDR. No statistically significant associations were found between patient age, gender, or HIV status and multidrug resistance.

The one isolate that had a silent mutation or synonymous single nucleotide polymorphism in $r p o B$ codon T508 $(\mathrm{ACC} \rightarrow \mathrm{ACT}$ ) was also analyzed by DST in the reference laboratory and found to be sensitive to rifampin. An additional 46 isolates, which were negative for mutations in the core region of $r p o B$, were also sent to the New York State Laboratory for control DST. All 46 isolates were sensitive to rifampin.

\section{Screening with GenoType MTBDRplus line-probe assay}

A line-probe assay was performed on DNA extracts from the $906 \mathrm{M}$. tuberculosis isolates. The MTBDRplus assay identified $28(3.1 \%)$ samples as resistant to rifampin. This number included all 27 isolates identified by sequencing as having a missense mutation or deletion in the

TABLE 2. Drug resistance of Mycobacterium tuberculosis isolates with mutations in $r p o B$ gene from 26 patients with new diagnosis of active pulmonary tuberculosis, Port-auPrince, Haiti, 2008

\begin{tabular}{|c|c|c|}
\hline \multirow[b]{2}{*}{ Drug resistance $\mathrm{a}^{\mathrm{a}}$} & \multicolumn{2}{|c|}{$\begin{array}{l}\text { Mycobacterium tuberculosis } \\
\text { isolates with rpoB mutations }\end{array}$} \\
\hline & No. & $\%$ \\
\hline Isoniazid & 26 & 100.0 \\
\hline Rifampin & 26 & 100.0 \\
\hline $\begin{array}{l}\text { Isoniazid and } \\
\text { rifampin (multidrug }\end{array}$ & & \\
\hline resistant) & 26 & 100.0 \\
\hline Ethambutol & 18 & 69.2 \\
\hline Pyrazinamide & 14 & 53.8 \\
\hline Streptomycin & 12 & 46.1 \\
\hline Ethionamide & 3 & 11.5 \\
\hline
\end{tabular}

${ }^{a}$ No strains were resistant to $p$-aminosalicylic acid, ofloxacin, capreomycin, cycloserine, kanamycin, or amikacin.

b Mutations include missense mutations or deletions in the 81-bp core region of $r p o B$ but do not include isolates with silent mutations or synonymous single nucleotide polymorphisms. $r p o B$ gene and the one isolate that had a synonymous single nucleotide polymorphism in $r p o B$ codon T508 (ACC $\rightarrow$ ACT). The remaining isolates were sensitive to rifampin by the MTBDRplus assay.

\section{DISCUSSION}

This study documents that at least $2.9 \%$ of patients newly diagnosed with smear-positive pulmonary TB in Portau-Prince had MDR M. tuberculosis. This value is an increase from two studies in the 1990s, when MDR-TB was not detected in any new TB cases in Haiti. This study also suggests that $r p o B$ sequencing or hybridization assays are good screening tools in this population for early detection and appropriate treatment of MDR-TB.

These data document that the rates of MDR-TB have increased in Haiti since studies in the 1990s showed that fewer than $1.0 \%$ of patients with newly diagnosed TB were resistant to isoniazid and rifampin $(7,8)$. Studies from the neighboring Dominican Republic, which shares the island of Hispaniola with Haiti, also have shown a high MDR-TB rate of $10.2 \%$ in all cases and $6.6 \%$ in new TB cases (11). Given the large amount of immigration between countries throughout the Western Hemisphere, the results of these studies are of particular concern for the spread of previously localized disease.

The results of this study have become even more relevant since the 12 January 2010 earthquake, when the headquarters of the National TB Program and several large TB treatment centers were destroyed, including three of the five centers that participated in this study (15). Thousands of TB patients in Portau-Prince defaulted on therapy and are now living in crowded tent cities. Rates of MDR-TB could climb even higher under these catastrophic conditions.

This study was limited in that goldstandard culture-based drug sensitivity testing was performed only on the samples that tested positive for $r p o B$ mutations and only on a subset of the isolates that were negative for the rpoB mutations. Therefore, the prevalence of MDR-TB may be underestimated. However, all 46 isolates without rpoB mutations tested negative for rifampin resistance by a standard culture method, and other studies suggest a $>95.0 \%$ correlation between $r p o B$ sequence analysis 
and phenotypic drug sensitivity testing. Therefore, it is unlikely that the actual rates of MDR-TB are significantly higher than $3.0 \%$.

At least $2.9 \%$ of patients newly diagnosed with smear-positive pulmonary tuberculosis in Port-au-Prince have MDR-TB. Sequencing or hybridization assays of the $r p o B$ gene are good screening tools in this population for early detection and appropriate treatment of MDR-TB.
Acknowledgments. This project was supported by Fondation Merieux and grants TW006896, TW006901, and TW00018 from the Fogarty International Center of the National Institutes of Health.

\section{REFERENCES}

1. World Health Organization. Global tuberculosis control: 2011. Geneva: WHO; 2011. Available from: http://www.who.int/tb/ publications/global_report/2011/gtbr11_ full.pdf Accessed 7 December 2011.

2. World Bank. The migration and remittances factbook 2011. Washington, D.C.: World Bank; 2011. Available from: http:// siteresources.worldbank.org/INTLAC/ Resources/Factbook2011-Ebook.pdf Accessed 9 January 2011.

3. Rivest $\mathrm{P}$, Tannenbaum LB, Bedard L. Epidemiology of tuberculosis in Montreal. Can Med Assoc J. 1998;158:605-9.

4. New York City Department of Health and Mental Hygiene. New York City is stopping TB. Annual summary 2008. New York: New York City Department of Health and Mental Hygiene; 2008. Available from: http:// www.nyc.gov/html/doh/downloads/pdf/ $\mathrm{tb} / \mathrm{tb}$ annualsummary08.pdf Accessed 22 November 2010

5. Schwartzman K, Oxlade O, Barr RG, Grimard F, Acosta I, Baez J, et al. Domestic returns from investment in the control of tuberculosis in other countries. N Engl J Med. 2005; 353:1008-20.
6. Cain KP, Benoit SR, Winston CA, MacKenzie WR. Tuberculosis among foreign-born persons in the United States, 1993-1998. JAMA. 2008;300:405-12.

7. Scalcini M, Carré G, Jean-Baptiste $M$, Hirshfield E, Parker S, Wolfe J, et al. Antituberculous drug resistance in central Haiti. Am Rev Respir Dis. 1990;142:508-11.

8. Malone JL, Paparello SF, Malone JD, Hill HE, Conrad KA, Myers JW, et al. Drug susceptibility of Mycobacterium tuberculosis isolates from recent Haitian migrants: correlation with clinical response. Clin Infect Dis. 1994;19:938-40.

9. Joseph P, Severe P, Ferdinand S, Goh KS, Sola C, Haas DW, et al. Multi-drug resistant tuberculosis at an HIV testing center in Haiti. AIDS. 2006;20:415-88.

10. Montoro E, Lemus D, Echemendía $M$, Armas L, González-Ochoa E, Llanes MJ, et al. Drug-resistant tuberculosis in Cuba. Results of the three global projects. Tuberculosis. 2006;86:319-23.

11. Espinal MA, Báez J, Soriano G, Garcia V, Laszlo A, Reingold AL, et al. Drug-resistant tuberculosis in the Dominican Republic: results of a nationwide survey. Int $\mathrm{J}$ Tuberc Lung Dis. 1998;2:490-9.
12. Ramaswamy S, Musser JM. Molecular genetic basis of antimicrobial agent resistance in Mycobacterium tuberculosis: 1998 update. Tuber Lung Dis. 1998;79(1):3-29.

13. Halse TA, Edwards J, Cunningham PL Wolfgang WJ, Dumas NB, Escuyer VE, et al. Combined real-time PCR and rpoB gene pyrosequencing for rapid identification of $\mathrm{Myco-}$ bacterium tuberculosis and determination of rifampin resistance directly in clinical specimens. J Clin Microbiol. 2010;48(4):1182-8.

14. National Committee on Clinical Laboratory Standards. Susceptibility testing of Mycobacteria, Nocardiae, and other aerobic Actinomycetes. Approved standard. NCCLS document M24-A. Wayne, Pennsylvania: NCCLS; 2003.

15. Pape JW, Johnson WD Jr, Fitzgerald DW. The earthquake in Haiti-dispatch from Port-auPrince. N Engl J Med. 2010;362:575-7.

Manuscript received on 19 June 2011. Revised version accepted for publication on 20 December 2011.

RESUMEN Objetivo. Determinar la prevalencia de tuberculosis (TB) multirresistente en pacientes con TB pulmonar nueva con baciloscopia positiva en Puerto Príncipe, Haití. Métodos. Se cultivaron muestras de esputo de 1006 pacientes con diagnóstico reciente de tuberculosis efectuado durante el 2008. Se secuenció la región nuclear del gen $r p o B$, que se asocia con la resistencia a la rifampicina. Todos los aislados con mutaciones de rpoB se enviaron al laboratorio de referencia del estado de Nueva York para llevar a cabo un antibiograma convencional. Todos los aislados se estudiaron también con el ensayo de sonda lineal GenoType MTBDRplus.

Resultados. Se aisló Mycobacterium tuberculosis de 906 pacientes. Veintiséis $(2,9 \%)$ de los aislados presentaban mutaciones de sentido erróneo o deleciones en $r p o B$ y fueron resistentes a la rifampicina en el antibiograma. Los 26 aislados fueron resistentes también a la isoniacida y se clasificaron como TB multirresistente. Cuarenta y seis aislados de control sin mutaciones de $r p o B$ resultaron sensibles a la rifampicina en el antibiograma. El ensayo de sonda lineal GenoType MTBDRplus identificó correctamente a las 26 cepas de TB multirresistente y clasificó de manera errónea un aislado sensible a múltiples fármacos como resistente a la rifampicina.

Conclusiones. Este estudio revela una prevalencia de TB multirresistente de 2,9\% en los pacientes con TB recién diagnosticada en Haití e indica que los ensayos de secuenciación e hibridación de $r p o B$ son estudios de detección sistemática adecuados para la detección temprana de la TB multirresistente.

Palabras clave Tuberculosis resistente a múltiples medicamentos; estudios transversales; Haití. 